\title{
TANGGUNGJAWAB PDAM KABUPATEN GIANYAR DALAM HAL TIDAK MENGALIRNYA AIR SECARA SEPIHAK KEPADA KONSUMEN DALAM PERSPEKTIF UNDANG-UNDANG NOMOR 8 TAHUN 1999
}

\author{
Komang Adika Bayu Mahendra, Anak Agung Sagung Laksmi Dewi, Ni Made Puspasutari Ujianti puspa \\ Fakultas Hukum Universitas Warmadewa, Denpasar-Bali, Indonesia \\ komangandika17@gmail.com, laksmiidewi29@gmail.com, niwapong@gmail.com
}

\begin{abstract}
Abstrak
Air merupakan suatu hal yang paling penting dalam rumah tangga maupun industri. Permasalahan yang sering terjadi di masyarakat mengenai air ialah tidak mengalirnya air kelalaian petugas PDAM yang dimana pihak konsumen yang paling beresiko mengalami kerugian. Penelitian ini bertujuan untuk mengkaji sanksi yang dikenakan kepada PDAM Kabupaten Gianyar terhadap kerugian konsumen atas tindakan tidak mengalimya air secara sepihak dan menganalisis perlindungan hukum bagi konsumen akibat kerugian atas tidak mengalirnya air secara sepihak. Metode yang digunakan adalah penelitian adalah hukum normatif dengan pendekatan Perundang-undangan dan konseptual. Sumber data adala bahan hukum primer dan bahan hukum sekunder, data ini diperoleh melalui wawancara dan studi kepustakaan. Selanjutnya data diolah dan dianalisis denga metode deskriptif kulaitatif. Hasil penelitian menunjukkan bahwa perlindungan konsumen diatur dalam Undangundang nomor 8 Tahun 1999. Pertanggung jawaban dari PDAM jika mendapat keluhan dari konsumen, yaitu pihak teknisi PDAM langsung mendatangi wilayah konsumen melakukan pengecekan penyebab dan titik permasalahan sehingga membuat air di wilayah atau rumah konsumen tidak mengalir. Sehingga dapat cepat ditanggulangi pihak PDAM. Upaya hukum yang dilakukan oleh pelaku usaha atau PDAM jika terjadinya sengketa pihak PDAM mengutamakan non litigasi dengan cara negosiasi serta mediasi secara bermusyawarah sehingga mendapatkan keputusan secara bersama.
\end{abstract}

Kata Kunci: Air, Konsumen, Pelaku Usaha.

\begin{abstract}
Water is the most important thing in household and industry. The problem that often occurs in the community regarding water is the non-flow of water, the negligence of PDAM officers, where the consumer is the most at risk of experiencing losses. This study aims to examine the sanctions imposed on PDAM Gianyar Regency for consumer losses for the act of not draining water unilaterally and analyzing legal protection for consumers due to losses for not flowing water unilaterally. The method used is the research is normative law with legislation and conceptual approach. Sources of data are primary legal materials and secondary legal materials, this data was obtained through interviews and literature study. Furthermore, the data is processed and analyzed using a qualitative descriptive method. The results of the study indicate that consumer protection is regulated in Law number 8 of 1999. The responsibility of the PDAM if they receive complaints from consumers, namely the PDAM technician directly goes to the consumer's area to check the cause and point of the problem so that water in the area or consumer's house does not flow. So that the PDAM can quickly deal with it. Legal remedies taken by business actors or PDAMs if there is a dispute, the PDAM prioritizes non-litigation by means of negotiation and mediation by deliberation so as to obtain a joint decision.
\end{abstract}

Keywords: Water, Consumers, Business Actors.

\section{PENDAHULUAN}

Sumber air menjadi hal yang sangat terpenting dalam kehidupan manusia. Air sangat mendukung jalannya kegiatan industri maupun rumah tangga. Air tidak dapat dihilangkan dari kehidupan semua manusia, apabila tidak adanya air di masyarakat aktivitas sehari-hari tidak bisa berjalan seperti biasa. Hal tersebut menunjukan betapa pentingnya keburuhan air yang sangat banyak bagi masyarakat. Sebagai warga Negara Indonesia seharusnya berbangga sekali karena wilayah Indonesia memiliki wilayah perairan yang sangat melimpah entah dari lautan, sungai, danau, teluk. Air bersih dari pegununganjuga salah satu sumber terbesar air yang dimiliki Negara Indonesia, sumber air ini yang 
paling bersih dan dijadikan sumber air khusunya PDAM (Kaunang et al., 2015) \& (Lestari \& Suprapto, 2017)

Angka kemakmuran manusia dan juga dengan mendorongnya kenaikan pola hidup tak dapat dilepas dari penyedian air yang baik. Pentingnya air bagi masyarakat dapat ditunjukkan dengan besarnya penggunaan air oleh masyarakat baik untuk konsumsi rumah tangga maupun industri. Adanya air menjadi salah satu sumber hidup manusia secara alami, yang dimana bersifatkan dinamis, air berasal dari gunung atau laut dan mengalir di setiap perairan mulai dari sungai, got maupun aliran air lainnya.

Ketersediaan air juga bergantung pada cuaca, yang dimana pada musim penghujan air akan lebih banyak tersedia daripada musim panas yang sangat sulit untuk mendapatkan air bersih dari aliran air. Pentingnya air dalam kehidupan sehingga air sendiri telah diatur dalam Pasal 33 Uundangundang Dasar 1945 ayat (2) dan ayat(3) dimana air selama ini digunakan dengan tidak baik oleh masyarakat yang jarang memperdulikan keberadaan air yang dapat habis suatu saat maka dari itu negara menciptakan pengaturan agar air dapat dijaga dan digunakan dengan baik dan bijak oleh masyarakat. Pemerintah sendiri telang memberikan mandat untuk menjaga keberadaan air dengan penggunaan yang baik pada pernerintah daerah dan diteruskan oleh suatu badan usaha milik daerah dengan diberikan nama perusahaan daerah air minum

Keburukan akan air bersih baik di desa, kota, maupun industri menjadikan pemanfaatan penggunaan air bersih menjadi berbeda fungsi pada umumnya. Penggunaan dan pemanfaatan air di setiap bidang entah di kota maupun desa dan juga industri, air dibutuhkan mencapai pada setiap masyarakat di tengah jumlah penduduk yang sangat banyak. Pengelolaan air bersih tersebut haruslah mernerlukan suatu lembaga untuk dapat menjalankan misi air bersih mencapai setiap penduduk entah di desa maupun dikota yang lebih banyak lagi penduduk. Dalam hal ini pemerintah membuat lembaga yakni perusahaan daerah air minum Pada zaman sekarang ini penduduk sangat banyak menggunakan air bersih yang disuplai oleh pihak PDAM.

Perlindungan terhadap konsumen dipandang secara material maupun formal makin terasa sangat penting, mengingat semakin majunya ilmu pengetahuan dan teknologi yang merupakan motor penggerak bagi produktivitas dan efisiensi produsen atas baran dan jasa yang dihasilkannya dalam rangka mencapai sasaran usaha. Dalam rangka mengejar dan mencapai kedua hal tersebut, akhimya baik langsung atau tidak langsung, konsumen lah yang pada umumnya akan merasakan dampaknya. Dengan demikian, upaya-upaya untuk memberikan perlindungan yang memadai terhadap kepentingan konsumen merupakan suatu hal yang penting dan mendesak untuk segera dicari solusinya, terutama di Indonesia, mengingat sedemikian kompleksnya permasalahan yang menyangkut perlindungan konsumen (Kristiyani, 2011).

Salah satu isu konsumen yang sering terjadi yaitu seringkali terjadi kemacetan air secara sepihak serta beberapa masalah lainnya yang disebabkan antara PDAM dengan konsumen (Sinaga, 2016). Kewajiban utama pelanggan atau konsumen pada PDAM ialah untuk membayar yuran air dengan waktu yang tepat, sebaliknya sebagai konsumen PDAM berhak mendapatkan air bersih setiap harinya dalam keadaan bersih (Novita \& Ritonga, 2018). Apabila terjadi masalah, konsumen PDAM berhak mendapatkan ganti rugi berupa tanggung jawab untuk perbaikan terhadap gangguan air yang dialami setiap konsumen yang sudah membayarkan setiap yuran kepada PDAM. Berdasarkan paparan sebelumnya maka, penelitian ini bertujuan untuk mengkaji sanksi yang dikenakan kepada PDAM Kabupaten Gianyar terhadap kerugian konsumen atas tindakan tidak mengalimya air secara sepihak dan menganalisis perlindungan hukum bagi konsumen akibat kerugian atas tidak mengalirnya air secara sepihak

\section{METODE PENELITIAN}

Penelitian ini didesain menggunakan penelitian hukum normatif dan didukung dengan data empiris. Pada pengkajian kasus hukum normatif ialah berupa pengkajian dimana mengkaji hukum tertulis dari setiap aspek, tapi tidak mengkaji aspek terapan maupun implementasinya. Sedangkan pendekatan masalah yang dipergunakan adalah pendekatan perundang-undangan, pendekatan konseptual dan pendekatan kasus. Persamaan Perundang-undangan ini dimana dilakukan cara melihat setiap pengaturan Perundang-undangan yang berkaitan dengan permasalahan (isu hukum yang sedang diteliti), sedangkan pendekatan konseptual adalah pendekatan yang beranjak dari pandanganpandangan serta doktrin-doktrin yang berkembang di dalam ilmu hukum guna memperjelas ide-ide 
dimana memberikan pengertian-pengertian hukum, konsep hukum, maupun asas hukum yang relevan dengan masalah yang dikaji. Serta pendekatan kasus yang berupa pendekatan yang dilakukan dengan cara menelaah pada kasus-kasus yang berkaitan dengan isu hukum. Bahan hukum yang digunakan adalah bahan hukumprimer dan sekunder yang dikumpulkan dengan metode wawancara dan analisis studi kepustakaan. Setelah semua data terkumpul selanjutnya dianalisis secara kualtatif deskriptif.

\section{HASIL DAN PEMBAHASAN}

\section{Sanksi yang Dikenakan Kepada PDAM Kabupaten Gianyar Terhadap Kerugian Konsumen atas Tindakan Tidak Mengalimya Air Secara Sepihak}

Sengketa konsumen ialah merupakan konflik dimana pelanggar hak setiap konsumen, dimana medannya menggapai setiap hal hukum, dalam keperdataan, pidana, dan juga dalam lingkup administrasi Negara. Sehingga Konsumen yang kurang peka terhadap bagaimana hak-haknya, maka seringkali akan melihat setiap pengajuan baik dengan pasal pencemaran nama baik, baik dengan memakai perangkat hukum perdata dan juga perangkat hukum pidana. Inginnya seseorang untuk mendapatkan keadilan biasanya harus membayar dengan tidak murah oleh konsumen (Nugroho, 2008). Sesuai UUPK menyatakan segala hak dan kewajiban sebagai penerima barang dan jasa dan juga penjual barang dan jasa tengah yang telah disebar dala sebagian aturan yang dapat dikumpulkan ke empat bagian besar, adalah industri, perdagangan, kesehatan dan lingkungan hidup. Namun tidak mungkin bagi beberapa orang konsumen yang tidak begitu paham dengan hukum mencari berbagai hal mengenai hak dan kewajibannya. Beberapa kelemahan dari peraruran-peraturan yang muncul sebelum UUPK adalah

1) Makna yang digunakan kadang tidak dikhususkan untuk perlindungan konsumen.

2) Letak konsumen lebih lemah

3) Tahapannya terlalu rumit dan sulit dipahami oleh konsumen.

4) Penyelesaian sengketa memakan waktu yang lama dan biayanya tinggi.

Menurut Hanito, (1984) Sengketa sebagai suatu situasi serta kondisi di mana masing-masing pihak, dua atau lebih yang memiliki perbedaan pendapat, yang merasa dirugikan maka setiap orang tersebut atau kedua belah pihak mengupayakan tercapainya misi kedua belah pihak yang tak bisa disatukan dan di mana kedua belah orang tersebut meyakini orang lain tentang suatu kebenaran yang ditujukan ke setiap dua belah pihak tersebut. Permasalahan antara dua belah pihak ialah dengan ada suatu perbedaan, perdebatan, perbedaan pendapat maupun ketidakpersamaan di antara masing-masing dua belah pendapat berbeda dimana bakal dan ingin adanya hubungan perikatan atau kerjasama anatara kedua pihak (Emerson, 2001) Pemecahan suatu masalah yang dilalui pengadilan dan digunakannya hukum acara telah ada dengan cara umum akan mengakibatkan suatu penerima jasa maupun barang selaras bersama tiap hukum acara dilihat salah satu contoh hukum acara perdata, penggugat seharusnya membuktikan agar tergugat telah melakukan hal yang merugikan kepada sang penggugat. Didalam masalah penerima jasa dan barang yang bersamaan dengan masalah perdata dimana langsung dibawa ke Pengadilan negeri, UUPK memaparkan setiap yang berwenang mengajukan gugatan adalah

a. Seseorang penerima jasa/barang dimana dirugikan atau ahli waris yang berhak.

b. Sekumpulan penerima barang/jasa yang merniliki kesamaan dalam misi dan visi.

c. Badan perlindungan konsumen swadaya masyarakat yang telah pantas, yakni di dalam setiap anggaran dasarnya menyatakan dengan tegas bahwa tujuan didirikannya organisasi tersebut ialah guna terlindunginya setiap konsumen dan telah melakukan kegiatan sesuai dengan anggaran dasarnya.

d. Pemerintah atau instansi terkait bila barang atau jasa yang dikonsumsi atau dimanfaatkan mengakibatkan ruginya setiap materi yang besar dan/atau korban yang tidak sedikit.

Prosedur yang dilakukan untuk menyelesaikan suatu permasalahan penerima jasa dan barang menggunakan jalur pengadilan ialah dilihat pada hukum acara perdata. Akan tetapi dilihat di dalam menyelesaikan permasalahan pihak yang rnelalui pengadilan berlakunya asas lex spesialis derogat lex generale, ialah berdasar pada pengaturan Pasal 64 yang pengaturannya hukum yang dipakai ialah hukum acara perdata sejauh enggan bertentangan pada UUPK. Bilamana munculnya permasalahan kedua belah pihak maka yang lakukan ialah ketentuan pada pengaturan UUPK.

Penyelesaian sengketa diluar pengadilan dapat mempertimbangkan hal-hal berikut:

a. Arbitrase 
Arbitrase ialah suatu upaya pengakhiran setia masalah perdata yang ada di luar peradilan umum dimana didasari oleh suatu perjanjian arbitrase dimana dibuat kedua belah pihak yang bersengketa berdasarkan perjanjian abrbitase secara tertulis oleh masing-rnasing pihak yang bersangkutan. Penyelesaian sengketa arbitrase sudah lama dikenal di Indonesia (Miru \& Yodo, 2014)

Pengakhiran masalah pada jalur peradilan arbitrase yakni bias diajukan oleh masing-masing orang yang sedang bermasalah, apabila kedua belah pihak tersebut telah mengajukan klausul arbitrase atau pokok-pokok perkaranya di dalam kesepakatan dimana dijadikan suatu masalah maupun adanya suatu kesepakatan arbitrase selepas munculnya masalah di dalam kedua para pihak. Kebaikan menyelesaikan masalah yang dilalui arbitrase karena kesepakatannya tidak ada keberlanjutan yaitu langsung final dan mempunyai kekuatan hukum tetap serta mengikat para pihak..

b. Konsiliasi

Konsiliasi merupakan salah satu alternatif penyelesaian sengketa yang juga dapat ditempuh di luar pengadilan, yang diartikan sebagai an independent person (conciliator) brings the parties together and encourages a mutually acceptable resolution of the dispute bt facilitating communication between the parties. Konsiliasi ini juga dimungkinkan sebagai alternatif penyelesaian sengketa konsumen berdasarkan Undang-undang perlindungan konsumen. Penyelesaian sengketa dengan cara ini merniliki banyak kesamaan dengan arbitrase, dan juga menyerahkan kepada pihak ketiga untuk memberikan pendapatnya tentang sengketa yang disampaikan oleh para pihak. Walaupun demikian, pendapat dari konsiliator tersebut tidak mengikat sebagaimana mengikatnya putusan arbitrase. Ketidakterikatan para pihak teradap pendapat yang diajukan oleh konsiliator mengenai sengketa.

c. Mediasi

Mediasi adalah suatu hal paling tepat dalam menyelesaikan setiap masalah diluar pengadilan, dan merupakan pilihan terbaik di dalam sistem dan bentuk ADR yang ada. Mediasi adalah suatu pemecahan masalah yang fleksibel dan tak rnelilit dimana mengajak orang ketiga netral, adalah seorang mediator, yang meringankan negosiasi antara masing-rnasing sengketa yang menjalankan mereka di dalam menyelesaikan sengketa sehingga memenuhi mufakat yang diterima oleh para pihak. Banyak definisi lain yang berbeda-beda menjelaskan tentang mediasi, dimana biasanya orang-orang mufakat akan pencapaiannya akan setiap jalan mediasi adalah membantu seseorang dimana sedang berperkara agar mewujudkan jalan keluar sengketa secara mandiri dalam hal setiap masalah dan juga konflik.

Berdasarkan hasil wawancara saya dengan lbu Dayu Sumiati pada hari Rabu tanggal 10 Februari 2021 yang merupakan Bagian Informasi Pelanggan di PDAM Tirta Sanjiwani Gianyar Menjelaskan tentang upaya penyelesaian hukum bagi konsumen akibat kerugian yang ditimbulkan oleh pdam atas tidak mengalirnya air secara sepihak. Upaya yang dilakukan pihak PDAM apabila tidak mengalirnya air di wilayah atau rumah konsumen maka pihak PDAM akan melakukan penanganan secara cepat kepada konsumen, dan apabila penanganan membutuhkan waktu lama untuk perbaikan maka pihak PDAM akan mendatangi konsumen untuk memberikan tangki air guna untuk melakukan pertanggungjawaban dari pihak PDAM itu sendiri.

\section{Upaya Perlindungan Hukum oleh PDAM Kabupaten Gianyar Terhadap Kerugian Konsumen atas Tidak Mengalirnya Air Secara Sepihak}

Undang-undang Nomor 8 Tahun 1999 tentang Perlindungan konsumen merupakan tumpuan hukum yang utama dalam penyelesaian permasalahan dan kasus-kasus tentang bagaimana perlindungan terhadap konsumen yang menderita kerugian akibat pelaku usaha yang kurang pemahaman dan kurang pekanya menyadari wewenang dan keharusan setiap orang pada hal melakukan suatu bisnisnya. Sebagai pelaku usaha sangat disarankan mengetahui dan mengilhami setiap hal yang dijadikan wewenang dan keharusan sebagai seorang yang akan melakukan bisnisnya, agar tak ada lagi pihak akan mengalarni kesusahan material dan non material dampak kurang cermat dan niat tidak baik dimana terus orang tersebut alami. Jika salah satu konsumen komplain karena merasa dirinya tidak diuntungkan pada setiap hasil dari produksi. Pelaku usaha berkewajiban dalam hal bertanggungjawab pada hasil yang diproduksi dan diperjualbelikan, maka adapun supaya selalu mendapatkan keselarasan bagi setiap orang yang menghasilkan suatu produk dan pembeli jasa/barang, maka sebagai pembeli tetap wajib ingat dalam melindungi dirinya, memilah suatu produk yang akan dibeli, di gunakan dan di konsumsinya. Perlindungan represif yaitu perlindungan terakhir yang dimana sanksi ataupun pemberian hal hal berupa lainnya. Perlindungan represif tersebut diberi pada 
penerima jasa atau barang. Jika pemakaian barang atau jasa tersebut yang dipakai pada penerima jasa/barang. Dengan kata lain seorang konsumen dapat diartikan tidak saja hanya sebagai penerima suatu barang maupun jasa. Dalam Undang-undang perlindungan konsumen sudah diatur secara lengkap mengenai sanksi-sanksi administrasi yang sudah cukup jelas pengaturannya sehingga dapat dijadikan dasar hukum dalam pelayanan air bersih di Kota Gianyar. Pemerintah di atas sebagai menjalankan tugasnya untuk Negara telah berupaya agar memberikan pasokan air bersih guna untuk mensejahterakan setiap masyarakatnya. Adapun cara didirikannya suatu perusahaan air bersih, yaitu PDAM (Perusahaan Daerah Air Minum). PDAM kota Gianyar sendiri memiliki nama PDAM Tlrta Sanitw Ani, dimana sampai saat ini PDAM kabupaten Gianyar belum bisa memenuhi pasokan air bersih yang memadai untuk dialirkan ke setiap rumah warga. Melihat hal ini masih banyaknya keluhan-keluhan dari konsumen terhadap pelayanan air bersih yang diproduksi oleh PDAM Kota Gianyar. Antara lain permasalahannya yaitu air mati, air keruh, lonjakan tagihan, perubahan golongan tarif, tagihan kadaluarsa, kesalahan administratif, dan denda merupakan permasalahan yang seringkali dikeluhkan oleh konsumen. Maka hal-hal yang diuraikan tersebut dapat disebut sebagai suatu pelanggaran hukum yang dilakukan oleh pelaku usaha (PDAM Kota Gianyar) kepada konsumennya. Sesuai dengan Pasal 6 Undang-undang Perlindungan Konsumen, berdasarkan penjelasan yang dimaksud tersebut maka konsumen berhak memahami hak-hak dari produsen, Sehingga diharapkan konsumen juga tidak merugikan pelaku usaha. Maka harus diingat kembali bahwa Undang-Undang Perlindungan Konsumen merupakan sebagai pelindung hukum bagi semua aturan lainnya yang masih berhubungan dengan perlindungan konsumen (Miru, 2011). Berdasarkan hasil wawancara saya dengan lbu Dayu Sumiati pada hari Rabu tanggal IO Februari 2021 yang rnerupakan Bagian Informasi Pelanggan di PDAM TIRTA SANJIW ANI GIANY AR menjelaskan tentang Upaya Perlindungan Hukum Oleh PDAM Kabupaten Gianyar Terhadap Kerugian Konsumen Atas Tidak Mengalirnya Air Secara Sepihak. Yang dimana sejauh ini konsumen datang langsung mendatangi kantor PDAM atau melalui telepon untuk menyampaikan keluhan mereka apabila terjadi tidak mengalirnya air. Upaya hukum yang selama ini dilakukan oleh pihak PDAM ialah dengan melalui non litigasi dengan konsumen yaitu lebih mengutamakan mediasi dan negosiasi.

\section{KESIMPULAN DAN SARAN}

\section{Simpulan}

Berdasarkan pebahasan dan hasil analisis data dapat ditarik simpulan sebagai bahwa tanggungjawab pihak PDAM apabila terjadi hal tersebut ialah pihak teknisi dari PDAM akan langsung mendatangi wilayah/rumah konsumen lalu melakukan pengecekan penyebab dan dimana titik permasalahan terjadi sehingga membuat air di wilayah atau rumah konsumen tidak mengalir. Kemudian pihak PDAM akan melakukan penanganan di bagian kerusakan yang membuat air tidak mengalir. Sejauh ini pihak PDAM melakukan tanggung jawabnya dengan melakukan perbaikan pada kerusakan entah dari pipa atau teknis lainnya. Upaya yang dilakukan pihak PDAM apabila tidak mengalirnya air, maka pihak PDAM akan melakukan penanganan secara cepat kepada konsumen, dan apabila penanganan membutuhkan waktu lama untuk perbaikan maka pihak PDAM akan mendatangi konsumen untuk memberikan tangki air guna untuk melakukan pertanggungjawaban dari pihak PDAM itu sendiri. Penyelesaian sengketa melalui 2 cara yaitu Penyelesaian sengketa melalui pengadilan dan di luar pengadilan. Penyelesaian dari suatu sengketa yang dan upaya hukum yang selama ini dilakukan oleh pihak PDAM ialah melalui non litigasi dengan konsumen yang lebih mengutamakan mediasi dan negosiasi.

\section{Saran}

Dari simpulan penelitian di atas adapu saran yang diberikan yaitu diharapkan kepada konsumen dan juga pihak pemberi jasa yaitu PDAM Kabupaten Gianyar harus saling tahu dan mengerti bagaimana hak dan kewajiban yang dimiliki setiap konsumen dan juga pihak pemberi jasa PDAM Kabupaten Gianyar. Dan apabila terjadi ketidaknyamanan di konsumen maka dapat menyalurkan keluhannya langsung terhadap pihak pemberi jasa agar dapat langsung ditangani. Selanjutnya pemerintah perlu melakukan pemantauan secara rutin atas kinerja dari perusahaan yang menjadi kontraktornya, agar kewajiban pemerintah memberikan pelayanan yang sebaik-baiknya bagi masyarakat dapat dicapai dengan baik. Optimalisasi peran dan tanggungjawab pemerintah dengan pemberlakuan reward dan punishment yang tegas terhadap kinerja PDAM Kabupaten Gianyar. 


\section{DAFTAR PUSTAKA}

Emerson, J. (2001). Alternatif Penyelesaian Sengketa di Luar Pengadilan Negosiasi, Mediasi, Konsiliasi dan Arbitrasi. Gramedia Pustaka. Jakarta.

Hanito, R. (1984). Hukum dan Masalah Penyelesaian Konflik. Majalah Fakultas Hukum UNDIP. Semarang.

Kaunang, C. D., Kawet, L., \& Halim, F. (2015). Pengembangan Sistem Penyediaan Air Bersih di Desa Kabupaten Minahasa Utara. Jurnal Sipil Statik, 3(6), 361-372.

Kristiyani, C. T. S. (2011). Hukum Perlindungan Konsumen. Sinar Grafika. Jakarta.

Lestari, D. T. B., \& Suprapto, H. (2017). Analisis Pemanfaatan Mata Air Sebagai Sumber Air Baku. Jurnal Desain Konstruksi, 16(2), 151-164.

Miru, A. (2011). Prinsip-Prinsip Perlindungan Konsumen di Indonesia. RajaGrafindo Persada. Jakarta.

Miru, A., \& Yodo, S. (2014). Hukum Perlindungan Konsumen. PT. Raja Grafindo Persada. Jakarta.

Novita, H. S., \& Ritonga, M. K. (2018). Pelaksanaan Hak dan Kewajiban Para Pihak dalam Perjanjian Berlangganan Air Bersih Antara PDAM Tirta Bina Labuhanbatu Rantauprapat Dengan Konsumen Menurut Undang-Undang No. 8 Tahun 1999. Jurnal Pembelajaran Dan Ilmu Civic, 2(1), 37-46.

Nugroho, S. A. (2008). Proses Penyelesaian Sengketa Konsumen Ditinjau dari Hukum Acara serta Kehendak lmplernentasinya. Kencana. Jakarta.

Sinaga, T. A. (2016). Perlindungan Hukum Bagi Konsumen air Minum atas Layanan PDAM Tirta Siak Kota Pekanbaru Ditinjau dari Undang-undang Nomor 8 Tahun 1999 tentang Perlindungan Hukum. Jurnal Fakultas Hukum, 3(2), 1-15. 